SUSTAINABLE FORESTRY

COLLECTION 81-82, 2020
ODRŽIVO SUMARSTVO

ZBORNIK RADOVA 81-82, 2020

UDK $630 * 182(497.11$ Kosmaj) $=111$

UDK 581.526.42(497.11 Kosmaj)=111

Original scientific paper

\title{
PHYTOSOCIOLOGICAL CHARACTERISTICS OF SESSILE OAK AND HORNBEAM FORESTS (QUERCO PETRAEAE-CARPINETUM BETULI RUDSKI 1949. S.L.) IN THE AREA OF KOSMAJ
}

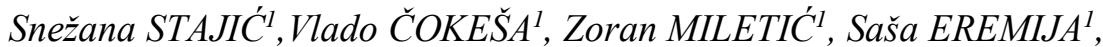 \\ Tatjana ĆIRKOVIĆ-MITROVIĆ , Mira MARKOVIĆ $^{\prime}$, Filip JOVANOVIĆ
}

\begin{abstract}
The paper presents phytosociological characteristics of the sessile oak and hornbeam community (Querco petraeae-Carpinetum betuli Rudski 1949. s.l.) in the area of Kosmaj. Phytosociological relevés of the investigated association were taken at altitudes ranging from 339 to $410 \mathrm{~m}$, with eastern to northeastern aspects, and the slope of 15-23. The community occurs on deeply ilimerized soils - luvisols over flysch. The floristic composition of this phytosociological community is diverse, including plants from thermophilicmand mesothermal oak forests and some plants from beech forests. With regard to the spectrum of range types, the investigated community Querco petraeae-Carpinetum betuli Rudski 1949. s.l. has a Central European range of distribution. Regarding the bioloigical spectrum of life forms, most species are considered phanerophytes and hemicryptophytes, with an increased share of geophytes.
\end{abstract}

Keywords: Kosmaj, protected area, sessile oak and hornbeam forest, spectra of life forms, spectra of range types.

\section{FITOCENOLOŠKE KARAKTERISTIKE ŠUME KITNJAKA I GRABA (QUERCO PETRAEAE-CARPINETUM BETULI RUDSKI 1949. S.L.) NA PODRUČJU KOSMAJA}

Izvod: U radu su prikazane fitocenološke karakteristike zajednice kitnjaka i graba (Querco petraeae-Carpinetum betuli Rudski 1949. s.l.) na području Kosmaja. Fitocenološki snimci istraživane asocijacije su sa nadmorskih visina 339-410 m, ekspozicije su istočne do

${ }^{1}$ Institute of Forestry, Belgrade, Serbia 
severoistočne, a nagib 15-23․ Geološka podloga na kojima se javlja ova zajednica je fliš, a zemljišta su duboka ilimerizovana - luvisoli. Floristički sastav ove fitocenoze je raznovrstan, jer su u njoj javljaju biljke iz termofilnih i mezotermnih hrastovih, ali i neke iz bukovih šuma. Prema spektru areal tipova proučena zajednica Querco petraeae-Carpinetum betuli Rudski 1949. s.l. ima srednjeevropski karakter, dok je prema spektru životnih oblika fanerofitskohemikriptofitskog karaktera, sa povećanim učešćem geofita.

Ključne reči: Kosmaj, zaštićeno područje, šuma kitnjaka i graba, spektri životnih oblika, spektri areal tipova.

\section{INTRODUCTION}

Since the end of the last and the beginning of this century, increasing attention has been paid to the preservation of endangered habitats and species. Considerable importance has been given to the segments of nature that are extremely affected by anthropogenic factors and have a large number of endangered plant and animal taxa. The research presented in this paper was performed in the territory of the Kosmaj Protected Area proclaimed a landscape of exceptional features in 2005. The general goal of the protection, management, and improvement of the state of protected areas includes the improvement of measures (conservation, rehabilitationrevitalization, and reclamation) and regimes of protection and monitoring of protected areas. Given that forest phytocenoses show the most observable signs of ecosystem degradation, the study of the vegetation of protected areas that includes defining and mapping of forest communities is imposed as a process that must be taken to achieve general goals.

The sessile oak and hornbeam forests in Serbia are conditioned by orographic and edaphic factors, i.e., they occur as extrazonal vegetation and cover significantly smaller areas than in the Illyrian province. They can be found as valley and mountain variants but without significant differences in the floristic composition (Tomić and Rakonjac, 2013). In the area of the Pešter Plateau, this community occurs in fragments at the altitude of 1010-1250 m (Ratknić and Rakonjac, 2010). According to Dinić $(1978 ; 1997)$, the sessile oak and hornbeam community represents a climate-regional type of forest growing on silicate rocks of small mountain massifs of northern Serbia, on the edge of the Pannonian Basin, at altitudes ranging from 300 to $600 \mathrm{~m}$ (Cer, Vidojevica, Avala, Fruška Gora, Miroč). This phenomenon is explained by several different factors: the origin and historical development of this area, the transitional nature of the climate, the isolated island character and low altitudes of these mountains, dislocated relief, and silicate bedrock.

This paper aims to study the phytosociological characteristics of the association of sessile oak and hornbeam in the investigated area of Kosmaj. Considering that most of the Kosmaj area has been declared a landscape of exceptional features, with significant natural, biological-ecological, aesthetic, and cultural-historical values, the research of the vegetation of this area can serve as a starting point for planning silvicultural needs as important factors related to the provision of special benefits of these forests. 


\section{RESEARCH AREA, MATERIAL AND METHOD OF WORK}

Kosmaj is a low and relatively small island mountain located in the vicinity of Belgrade. Over $70 \%$ of the mountain itself is covered in forest vegetation, dominantly oak and beech coppice stands. There are also artificially-established stands.

According to Thorntwhite climate classification, this area is dominated by subhumid climate - type C2 (Stajić, S., 2016). The mean annual air temperature is $12.3^{\circ} \mathrm{C}$, while it amounts to $18.9^{\circ} \mathrm{C}$ in the growing season. The mean annual rainfall is $696 \mathrm{~mm}$, about $57 \%$ of which falls in the growing season. Mt. Kosmaj is characterized by a specific bedrock composition (Neogene sands and clays, marls, limestones, breccias, sandstones, and serpentinite) which has brought about significant soil diversity of the area.

The Braun-Blanquet method (Braun-Blanquet, 1964) was applied for the analysis of the floristic composition and production of a synthetic table. Plant species were determined based on the following literature sources: Flora of Serbia I-X (Josifović et al., 1972-1977, Sarić et al., 1986; 1992; Stevanović et al., 2012). The spectra of floral elements were determined using the systematization of phytogeographical elements created by Gajić (1980) and the spectra of life forms using the method of Kojić et al., (1997). The community was classified using the syntaxonomic classification of Tomić and Rakonjac (2013).

Soil types were determined in all sites where relevés were collected. A soil profile was opened on a representative surface area, the type of soil was determined and soil samples were taken in disturbed condition for the laboratory study of the most important physical and chemical properties.

\section{RESULTS AND DISCUSSION}

\subsection{Environmental conditions}

Based on the floristic composition, it was determined that the relevés belong to the community of sessile oak and hornbeam (Querco petraeae-Carpinetum betuli Rudski 1949. s.1.). The relevés of the investigated association were taken at 339-410 $\mathrm{m}$ a.s.l. They have eastern to northeastern aspects and the slopes of $15-23^{\circ}$. The underlying bedrock of the forest community is flysch.

\subsection{Soil characteristics}

According to the study results, the community of sessile oak and hornbeam (Querco petraeae-Carpinetum betuli Rudski 1949 s.l.) grows on ilimerized soil luvisol, with an A-E-Bt-C profile structure. The soil profile was opened at an altitude of $339 \mathrm{~m}$, on a slope of $19^{\circ}$ and eastern aspect. The depth of the analyzed ilimerized soil was $85 \mathrm{~cm}$. The soil was skeleton-poor, and rock fragments were found mainly in the deeper parts of the illuvial horizon, while the surface layers of the profile had no skeleton. The humus-accumulative horizon is intermittent so that the eluvial horizon begins just below the soil litterfall. Regarding the soil texture, horizon A belongs to sandy loams. It is poorly structured with unstable structural aggregates. 
The eluvial horizon (E) is poorly structured and according to its texture belongs to clays. Below the eluvial horizon, there is a brown illuvial Bt horizon. The texture of the illuvial horizon in the analyzed profile belongs to clay loams. The reaction of the soil solution of the humus-accumulative horizon is moderately acidic. Moving to the eluvial horizon, the $\mathrm{pH}$ value of the soil solution, as a rule, decreases and then increases again in the illuvial horizon. Considering the content of humus, the humusaccumulative horizon is humus-rich, but the capacity of the humus horizon is small. The eluvial horizon is poor and the illuvial horizon is very poor in humus.

\subsection{Floristic composition}

The community of sessile oak and hornbeam (Querco petraeae-Carpinetum betuli Rudski 1949 s.l.) is found only in fragments which are presented with three relevés from Mali Kosmaj (Table 1). The floristic composition of this forest community is diverse. It includes plants from thermophilic and mesothermal oak forests and some beech forests plants.

The stands are of coppice origin. The average tree height is $21-22 \mathrm{~m}$. The canopy is dense (0.8). Besides the dominant presence of the edifying sessile oak (Quercus petraea (Matt.) Liebl) and hornbeam (Carpinus betulus L.) trees, there are trees of flowering ash (Fraxinus ornus L.) in the tree layer. There are also individual trees of Acer campestre L., Ulmus minor Mill., Quercus cerris L., and Quercus farnetto Ten. The shrub layer is rich in species, with a total of 12 species registered, and the canopy ranges from 0.3 to 0.8 . Besides hornbeam (Carpinus betulus L.), the most frequent species include Fraxinus ornus L., Crataegus oxyacantha L., Acer campestre L., Cornus mas L., Ligustrum vulgare L., Ruscus aculeatus L., Rosa canina L., Prunus spinosa L., Crataegus monogyna Jacq., Cornus sanguinea L. and Pyrus pyraster Burg.

Table 1. Phytosociological table of Querco petraeae-Carpinetum betuli Rudski 1949. s.l. association

\begin{tabular}{|c|c|c|c|c|}
\hline Association & \multicolumn{4}{|c|}{ Querco petraeae-Carpinetum betuli Rudski 1949. s.l } \\
\hline Subassociation & \multirow{2}{*}{\multicolumn{3}{|c|}{$\begin{array}{c}\text { aculeatetosum } \\
\text { Kosmaj }\end{array}$}} & \multirow{14}{*}{ 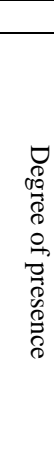 } \\
\hline Locality & & & & \\
\hline Relevé & 1 & 2 & 3 & \\
\hline Size $\left(\mathrm{m}^{2}\right)$ & 900 & 900 & 900 & \\
\hline Altitude (m) & 410 & 339 & 393 & \\
\hline Aspect & E-NE & $\mathrm{E}$ & $\mathrm{NE}$ & \\
\hline Slope $\left(^{\circ}\right)$ & 17 & 23 & 15 & \\
\hline Bedrock & \multicolumn{3}{|c|}{ Flysch } & \\
\hline Soil & \multicolumn{3}{|c|}{ Ilimerized soil } & \\
\hline \multicolumn{4}{|c|}{ Layer I } & \\
\hline Crown canopy & 0,8 & 0,8 & 0,8 & \\
\hline Mean height (m) & 22,0 & 21,0 & 22,0 & \\
\hline Mean diameter $(\mathrm{cm})$ & 30,0 & 28,0 & 22,0 & \\
\hline Spacing (m) & 8,0 & 7,0 & 5,0 & \\
\hline Quercus petraea & 4.4 & 4.5 & 5.5 & $\mathrm{~V}$ \\
\hline Carpinus betulus & 1.1 & 1.1 & 1.2 & $\mathrm{~V}$ \\
\hline Fraxinus ornus & 1.1 & + & 1.1 & $\mathrm{~V}$ \\
\hline Acer campestre & & & 1.1 & II \\
\hline Ulmus minor & & & 1.1 & II \\
\hline Quercus cerris & & +.1 & & II \\
\hline Quercus farnetto & +.1 & & & II \\
\hline
\end{tabular}




\begin{tabular}{|c|c|c|c|c|}
\hline \multicolumn{5}{|c|}{ Layer II } \\
\hline Crown canopy & 0,8 & 0,7 & 0.3 & \\
\hline Fraxinus ornus & 3.3 & 3.3 & 1.1 & $\mathrm{~V}$ \\
\hline Crataegus oxyacantha & 2.1 & 1.1 & 3.1 & $\mathrm{~V}$ \\
\hline Acer campestre & 2.1 & 1.1 & 2.1 & $\mathrm{~V}$ \\
\hline Cornus mas & 1.2 & 1.1 & 1.1 & $\mathrm{~V}$ \\
\hline Ligustrum vulgare & 2.3 & & 2.3 & IV \\
\hline Carpinus betulus & 1.1 & 2.2 & & IV \\
\hline Ruscus aculeatus & 1.3 & 2.3 & & IV \\
\hline Rosa canina & 1.1 & 2.2 & & IV \\
\hline Prunus spinosa & 2.2 & +.1 & & IV \\
\hline Crataegus monogyna & & & 1.1 & II \\
\hline Cornus sanguinea & & & 1.1 & II \\
\hline Pyrus pyraster & +.1 & & & II \\
\hline \multicolumn{5}{|c|}{ Layer III } \\
\hline Cover & 0,4 & 0,7 & 0,6 & \\
\hline Tamus communis & 3.1 & 2.1 & 3.3 & $\mathrm{~V}$ \\
\hline Euphorbia amygdaloides & 2.2 & 2.3 & 2.2 & $\mathrm{~V}$ \\
\hline Cardamine bulbifera & 2.1 & 2.1 & 2.1 & $\mathrm{~V}$ \\
\hline Brachypodium sylvaticum & 1.2 & 2.2 & 1.2 & $\mathrm{~V}$ \\
\hline Quercus petraea & 1.1 & 2.1 & 2.3 & $\mathrm{~V}$ \\
\hline Ruscus aculeatus & 1.2 & 1.3 & 2.3 & $\mathrm{~V}$ \\
\hline Hedera helix & 3.1 & & 3.3 & IV \\
\hline Glechoma hirsuta & 2.2 & & 3.3 & IV \\
\hline Carex pilosa & 2.2 & & 3.3 & IV \\
\hline Carex sylvatica & 2.3 & 2.2 & & IV \\
\hline Chaerophyllum temulum & 2.2 & 2.1 & & IV \\
\hline Crataegus oxyacantha & 2.1 & & 2.1 & IV \\
\hline Lathyrus venetus & 2.1 & 2.1 & & IV \\
\hline Helleborus odorus & 1.1 & & 2.1 & IV \\
\hline Acer campestre & 2.1 & & 1.1 & IV \\
\hline Lonicera caprifolium & 2.1 & & 1.1 & IV \\
\hline Fragaria vesca & 2.1 & & 1.1 & IV \\
\hline Bilderdykia convolvulus & & 2.1 & +.1 & IV \\
\hline Carpinus betulus & & 1.1 & 1.1 & IV \\
\hline Mycelis muralis & & 1.1 & 1.1 & IV \\
\hline Ajuga reptans & & 1.1 & +.1 & IV \\
\hline Poa nemoralis & & 2.2 & & II \\
\hline Galium schultesii & & 3.3 & & II \\
\hline Moehringia trinervia & & & 2.3 & II \\
\hline Lathyrus vernus & & & 2.1 & II \\
\hline Rubus canescens & & 1.3 & & II \\
\hline Dactylis glomerata & & 1.2 & & II \\
\hline Carex divulsa & & 1.2 & & II \\
\hline Festuca ovina & & 1.2 & & II \\
\hline Polygonatum odoratum & & & 1.2 & II \\
\hline Galium aparine & & & 1.2 & II \\
\hline Rubus hirtus & 1.1 & & & II \\
\hline Viola hirta & 1.1 & & & II \\
\hline Lapsana communis & & 1.1 & & II \\
\hline Calamintha vulgaris & & 1.1 & & II \\
\hline Quercus cerris & & 1.1 & & II \\
\hline Crataegus monogyna & & 1.1 & & II \\
\hline Hypericum hirsutum & & 1.1 & & II \\
\hline Campanula patula & & 1.1 & & II \\
\hline Veronica chamaedrys & & 1.1 & & II \\
\hline Lamium maculatum & & 1.1 & & II \\
\hline Cornus sanguinea & & & 1.1 & II \\
\hline Ligustrum vulgare & & & 1.1 & II \\
\hline Clematis vitalba & & & 1.1 & II \\
\hline Geum urbanum & & & 1.1 & II \\
\hline
\end{tabular}




\begin{tabular}{|l|c|c|c|c|}
\hline Geranium robertianum & & & 1.1 & II \\
\hline Circaea lutetiana & & & 1.1 & II \\
\hline Rumex sanguineus & & & 1.1 & II \\
\hline Ulmus minor & & & 1.1 & II \\
\hline Doronicum columnae & & & 1.1 & II \\
\hline Asparagus tenuifolius & & & 1.1 & II \\
\hline Rosa arvensis & & & 1.1 & II \\
\hline Asperula odorata & +.1 & & & II \\
\hline Scrophularia nodosa & & & +.1 & II \\
\hline Campanula persicifolia & & & +.1 & II \\
\hline Lilium martagon & & & +.1 & II \\
\hline Prunus avium & & + & & II \\
\hline Fagus moesiaca & + & & & II \\
\hline Silene viridiflora & & + & & II \\
\hline
\end{tabular}

There is a total of 59 species in the ground flora layer. The coverage is 0.4 to 0.7. Besides the edifying sessile oak and hornbeam, the species with the highest degree of presence in the ground flora layer include Tamus communis L., Euphorbia amygdaloides L., Cardamine bulbifera (L.) Crantz., Brachypodium sylvaticum (Huds.) Beauv., Hedera helix L., Glechoma hirsuta Waldst. \& Kit., Carex pilosa Scop., Carex sylvatica Huds., Chaerophyllum temulum L., Crataegus oxyacantha L., Lathyrus venetus (Miller) Wohlf., Helleborus odorus Waldst. \& Kit., Acer campestre L., Lonicera caprifolium L., Fragaria vesca L, Bilderdykia convolvulus (L.) Dumort., Mycelis muralis (L.) Dum., Ajuga reptans L., etc.

The floristic composition is characterized by the presence of the Mediterranean floral element - butcher's-broom (Ruscus aculeatus L.), which is the reason the aculeatetosum subassociation has been singled out. The forest of sessile oak and hornbeam with butcher's-broom is recorded in the northern part of Šmadija, on the edge of the Pannonian Basin, influenced by the climate of the Pannonian Plain, on one side and small mountain massifs that are colder and wetter on the other side (Dinić, 1997). It is most similar to the forest of the Illyrian province Epimedio-Carpinetum betuli (Horv. 38) Bor. 1963. ruscetosum of the Pannonian part of eastern Croatia and northeastern Bosnia (Tomić and Rakonjac, 2013). This community is most widely represented on Fruška Gora at altitudes of 300-500 m (Tomić and Rakonjac, 2013), and it also occurs on Mt. Avala (Borisavljević et al., 1955).

The mesophilic character of the community, which can be easily recognized by the composition of species in the ground flora layer, is also determined by the combination of the following site factors: shaded positions, relatively high air humidity and soil moisture, as well as deep ilimerized soils of moderately acidic reaction. The share of multi-seeded hawthorn (Crataegus oxyacantha L.) in the floristic composition is significant. It is a species of suboceanic climate, and as such, it is far more sensitive to the continental character of the climate than the singleseeded hawthorn (Crataegus monogyna Jacq.). It mainly grows on the fresh soil of the oak belt. On the other hand, there are some xerothermic species of the zonal vegetation of Hungarian oak and Turkey oak forest, such as Quercus cerris L., Quercus frainetto Ten., Pyrus pyraster L., Cornus mas L. 


\subsection{Spectrum of floral elements}

Based on the analysis of the spectrum of floral elements (Table 2), it can be concluded that the community of Querco petraeae-Carpinetum betuli Rudski 1949 s.l. is predominated by plant species of the Central European range type. Their share amounts to $32 \%$. They are followed by plant species of the Eurasian range type (24\%), Submediterranean (12\%), Pontic (9\%), Subatlantic (9\%), Circumpolar (8\%), Balkan $(5 \%)$ and Subboreal type (1\%).

On the whole, the community of sessile oak and hornbeam (Querco petraeae-Carpinetum betuli Rudski 1949 s.1.) has the greatest share (41\%) of mesophilic plants (Central European and Subatlantic range types), which confirms the mesophilic character of this community. They are followed by xerothermophilic plants with 26\% (Pontic, Submediterranean and Balkan range types) and plants of wide ecological amplitude with $24 \%$ (Eurasian range types), while there are only $1 \%$ of Subboreal floral elements.

Table 2. Spectrum of floral elements in the community of Querco petraeaeCarpinetum betuli Rudski 1949. s.l.

\begin{tabular}{|c|c|c|c|c|c|}
\hline Range types & Num. & $\begin{array}{l}\text { Aggreagate } \\
\text { range types }\end{array}$ & $\begin{array}{l}\mathrm{Nu} \\
\mathrm{m} .\end{array}$ & \multicolumn{2}{|c|}{ Share $(\%)$} \\
\hline Subpontic & 1 & \multirow{4}{*}{ Pontic } & \multirow{4}{*}{6} & \multirow{4}{*}{$9 \%$} & \multirow{9}{*}{$26 \%$} \\
\hline Subpontic-subpannonian & 1 & & & & \\
\hline Pontic-submediterranean & 2 & & & & \\
\hline $\begin{array}{l}\text { Pontic-Eastern } \\
\text { submediterranean }\end{array}$ & 2 & & & & \\
\hline Submediterranean & 5 & \multirow{2}{*}{ Submediterranean } & \multirow{2}{*}{8} & \multirow{2}{*}{$12 \%$} & \\
\hline Eastern submediterranean & 3 & & & & \\
\hline Subbalkan-Apennine & 1 & \multirow{3}{*}{ Balkan } & \multirow{3}{*}{3} & \multirow{3}{*}{$5 \%$} & \\
\hline Moesian & 1 & & & & \\
\hline Central Balkan & 1 & & & & \\
\hline Central European & 4 & \multirow{2}{*}{ Central European } & \multirow{2}{*}{21} & \multirow{2}{*}{$32 \%$} & \multirow{3}{*}{$41 \%$} \\
\hline Sub-Central European & 17 & & & & \\
\hline Subatlantic-submediterranean & 6 & Subatlantic & 6 & $9 \%$ & \\
\hline Eurasian & 8 & \multirow{3}{*}{ Eurasian } & \multirow{3}{*}{16} & \multirow{3}{*}{$24 \%$} & \multirow{3}{*}{$24 \%$} \\
\hline Subeurasian & 5 & & & & \\
\hline Sub-South Siberian & 3 & & & & \\
\hline Circumpolar & 2 & \multirow{2}{*}{ Circumpolar } & \multirow{2}{*}{5} & \multirow{2}{*}{$8 \%$} & \multirow{2}{*}{$8 \%$} \\
\hline Sub-Circumpolar & 3 & & & & \\
\hline Subboreal-circumpolar & 1 & Subboreal & 1 & $1 \%$ & $1 \%$ \\
\hline Total: & 66 & Total: & 66 & $100 \%$ & $100 \%$ \\
\hline
\end{tabular}

The significant share of submediterranean floral elements in this community points to its relative thermophilicity. Abundant presence of plants of subatlanticsubediterranean floral element, such as Ruscus aculeatus L., Euphorbia amygdaloides L., Hedera helix L. and Tamus communis L. indicates a favorable phytoclimate of this forest, where these plants have found favorable conditions for their growth. 


\subsection{Spectrum of life forms}

The analysis of the spectrum of life forms (Table 3) shows that the investigated community of Querco petraeae-Carpinetum betuli Rudski 1949 s.l is predominated by phanerophytes with $38 \%$ (pure phanerophytes, nanophanerophytes, and phanerophytic vines). Hemicryptophytes also have a high share, accounting for $33 \%$.

The share of geophytes is also high (15\%), which indicates wet climate and soil conditions. Plants of the transitional category of therophytes to hamephytes are much less represented with $8 \%$, while the therophytes and herbaceous hamephytes have the smallest share of $3 \%$, each.

Table 3. Spectrum of life forms in Querco petraeae-Carpinetum betuli Rudski 1949. s.l. forest community

\begin{tabular}{|c|c|c|c|c|c|c|c|}
\hline \multicolumn{7}{|c|}{$\mathrm{fr}$} \\
\hline $\mathrm{P}$ & $\mathrm{Np}$ & $\mathrm{Pl}$ & $\mathrm{Zc}$ & $\mathrm{H}$ & $\mathrm{G}$ & $\mathrm{T}$ & $\mathrm{Th}$ \\
\hline $20 \%$ & $17 \%$ & $1 \%$ & $3 \%$ & $33 \%$ & $15 \%$ & $3 \%$ & $8 \%$ \\
\hline & $38 \%$ & & $3 \%$ & & & &
\end{tabular}

Legend: P-phanerophyte; Np-nanophanerophyte; Pv-phanerophytic vine; Hc-herbaceous chamaephyte; H-hemicryptophyte; G-geophyte; T-therophyte; Th-therophyte/ chamaephyte.

A similar biological spectrum, as well as the spectrum of life forms, is stated by Cvjetićanin et al., (2013) for the community of sessile oak and hornbeam on Miroč, where this community was recorded at altitudes ranging from 390 to $430 \mathrm{~m}$.

\section{CONCLUSION}

The community of sessile oak and hornbeam (Querco petraeae-Carpinetum betuli Rudski 1949 s.l.) in the area of Kosmaj occurs only in fragments which are presented with three relevés from Mali Kosmaj. The underlying bedrock of the community is flysch, and the soils are deeply ilimerized - luvisols.

Relevés were taken at altitudes ranging from 339 to $410 \mathrm{~m}$, eastern to northeastern aspects, and the slope of $15-23^{\circ}$. The mesophilic character of this community can easily be recognized by the characteristic set of species, most often found in the sessile oak-hornbeam forests of Serbia, which is determined by a combination of site factors. This is also indicated by the abundant presence of plants of the subatlantic-submediterranean floral element, such as Ruscus aculeatus L., Euphorbia amygdaloides L., Hedera helix L. and Tamus communis.

A distinctive feature of this sessile oak-hornbeam forest is the presence of butcher's-broom (Ruscus aculeatus L.), a submediterranean species that is found in Serbia only in the warmest Pontic-Pannonian part.

According to the spectrum of range types, the investigated sessile oak and hornbeam community (Querco petraeae-Carpinetum betuli Rudski 1949 s.l.) has a Central European character, while the prevailing life forms include phanerophytehemicryptophytes, with an increased share of geophytes.

The goals of multipurpose silviculture in special-purpose forests can be achieved by applying the close to nature silviculture, where the natural site potential 
is optimally used to preserve their naturalness, biodiversity and genetic variability, improve the condition and increase productivity. Therefore, the research of vegetation in this area is the starting point for planning silvicultural needs as important factors related to the provision of special benefits of these forests.

Note: This study was realized within the Agreement on realization and financing of scientific research work of NIO in 2020, which is financed by the Ministry of Education, Science and Technological Development of the Republic of Serbia, no. 451-03-68 / 2020-14 / 200027 dated 24.01.2020.

\section{REFERENCES}

Braun-Blanquet J. (1964): Pflanzensoziologie: Grundzüge die Vegetationskunde. Springer Verlag, Wien-New York.

Cvjetićanin R., Košanin O., Krstić M., Perović M., Novaković-Vuković M. (2013): Phytosociological and edaphic characteristics of sessile oak forests on Miroč Mountain in north-eastern Serbia. Bulletin of the Faculty of Forestry 107: 27-56.

Dinić, A. (1978): Phytocenosis of sessile oak and hornbeam as a climate regional forest type on small massifs in northern Serbia, on the edge of the Pannonian Plain. Matica Srpska Journal of Natural Sciences, Novi Sad, 55: 155-163.

Dinić, A. (1997): Association of sessile oak-hornbeam and pure hornbeam forests. In Sarić, M. Vasić, O. (eds.): Vegetation of Serbia II, forest communities, 1. Serbian Academy of Sciences and Arts - Department of Natural and Mathematical Sciences, Belgrade.

Gajić M. (1980): Overview of species of flora of Serbia by phytogeographical indications. Bulletin of the Faculty of Forestry 54: 111-141.

Josifović, M. (ed.) (1970-1977): Flora of Serbia II-IX. Serbian Academy of Sciences and Arts, Department of Natural and Mathematical Sciences, Belgrade.

Kojić M., Popović R., Karadžić B. (1997). Vascular plants of Serbia. Institute for Agricultural Research "Serbia" and Institute for Biological Research "Sinisa Stankovć", Belgrade.

Ratknić, M., Rakonjac, Lj. (2010): Sessile oak and hornbeam forest resources in Pešter Plateau. Sustainable Forestry, 61-62: 27-39.

Sarić, M, Diklić, N. (eds) (1986): Flora of Serbia X. Serbian Academy of Sciences and Arts, Department of Natural and Mathematical Sciences, Belgrade.

Sarić, M. (ed.) (1992): Flora of Serbia I. Serbian Academy of Sciences and Arts, Department of Natural and Mathematical Sciences, Belgrade.

Stevanović, V. (ed.) (2012): Flora of Serbia II. Serbian Academy of Sciences and Arts, Department of Natural and Mathematical Sciences, Belgrade. 
Stajić, S. (2016): Determination of forest phytocenoses of Kosmaj by combining standard phytosociological method and photointerpretation. Doctoral dissertation, Faculty of Forestry, University of Belgrade, Belgrade.

Tomić, Z., Rakonjac, Lj. (2013): Forest phytocenoses of Serbia. Institute of Forestry, Belgrade, Singidunum University - Faculty of Applied Ecology Futura, Belgrade.

\title{
PHYTOSOCIOLOGICAL CHARACTERISTICS OF SESSILE OAK AND HORNBEAM FORESTS (QUERCO PETRAEAE-CARPINETUM BETULI RUDSKI 1949. S.L.) IN THE AREA OF KOSMAJ
}

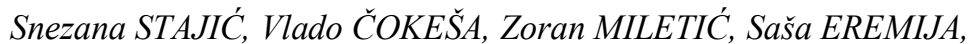 \\ Tatjana ĆIRKOVIĆ-MITROVIĆ, Mira MARKOVIĆ, Filip JOVANOVIĆ
}

\section{Summary}

The paper presents the results of the phytosociological research of sessile oak and hornbeam forests (Querco petraeae-Carpinetum betuli Rudski 1949 s.l.) conducted in the Kosmaj Protected Area. The sessile oak and hornbeam forests in Serbia are conditioned by orographic and edaphic factors, i.e., they occur as extrazonal vegetation and cover significantly smaller areas than in the Illyrian province. They can be found as valley and mountain variants but without significant differences in the floristic composition. The community of sessile and hornbeam in this area is found only in fragments that are presented with three relevés from Mali Kosmaj. Phytosociological relevés of the investigated association were taken at altitudes ranging from 339 to $410 \mathrm{~m}$., with eastern to northeastern aspects, and the slope of $15-23^{\circ}$. The community occurs on deeply ilimerized soils - luvisols over flysch.

The floristic composition of this phytosociological community is diverse, including plants from thermophilic and mesothermal oak forests and some plants from beech forests. In the tree layer, besides the dominant share of edifying sessile oak (Quercus petraea (Matt.) Liebl) and hornbeam (Carpinus betulus L.), there are: Acer campestre L., Ulmus minor Mill., Quercus cerris L., and Quercus farnetto Ten. The shrub layer is rich in species, with a total of 12 species registered. There is a total of 59 species in the ground flora layer. There are plants of thermophilic and mesothermal oak forests and some beech forests plants. The mesophilic character of this community is pronounced, which is also indicated by the abundant presence of plants of the subatlantic-submediterranean floral element, such as Ruscus aculeatus L., Euphorbia amygdaloides L., Hedera helix L. and Tamus communis. The floristic composition is characterized by the presence of the Mediterranean floral element of the butcher's-broom (Ruscus aculeatus L.), which is the reason the aculeatetosum subassociation has been singled out.

With regard to the spectrum of range types, the investigated community Querco petraeae-Carpinetum betuli Rudski 1949. s.l. has a Central European range of distribution. Regarding the biological spectrum of life forms, the prevailing life forms include phanerophyte-hemicryptophytes, with an increased share of geophytes.

Considering that most of the Kosmaj area is a protected area with significant natural, biological-ecological, aesthetic and cultural-historical values, the research of vegetation of this area can serve as the starting point for planning silvicultural needs as important factors related to the provision of special benefits of these forests. 


\title{
FITOCENOLOŠKE KARAKTERISTIKE ŠUME KITNJAKA I GRABA (QUERCO PETRAEAE-CARPINETUM BETULI RUDSKI 1949. S.L.) NA PODRUČJU KOSMAJA
}

\author{
Snežana STAJIĆ, Vlado ČOKEŠA, Zoran MILETIĆ, Saša EREMIJA, \\ Tatjana ĆIRKOVIĆ-MITROVIĆ, Mira MARKOVIĆ, Filip JOVANOVIĆ
}

\section{Rezime}

U radu su prikazani rezultati fitocenoloških istraživanja šume kitnjaka i graba (Querco petraeae-Carpinetum betuli Rudski 1949. s.1.) koja su sprovedena u zaštićenom području Kosmaj. Šume kitnjaka i graba u Srbiji su orografsko-edafski uslovljene, tj. javljaju se kao ekstrazonalna vegetacija i pokrivaju znatno manje površine nego u ilirskoj provinciji. Javljaju se u dolinskoj i brdskoj varijanti, ali bez većih razlika u florističkom sastavu. Zajednica kitnjaka i graba na ovom području zastupljena je samo fragmentarno i predstavljena je sa tri fitocenološka snimka sa Malog Kosmaja. Fitocenološki snimci istraživane asocijacije su sa nadmorskih visina 339-410 m, ekspozicije su istočne do severoistočne, a nagib $15-23^{\circ}$. Geološka podloga na kojima se javlja ova zajednica je fliš, a zemljišta su duboka ilimerizovana - luvisoli.

Floristički sastav ove fitocenoze je raznovrstan, jer su u njoj javljaju biljke iz termofilnih i mezotermnih hrastovih, ali istovremeno i neke iz bukovih šuma. U spratu drveća pored dominantnih edifikatora kitnjaka (Quercus petraea (Matt.) Liebl) i graba (Carpinus betulus L.) javljaju se: Fraxinus ornus L., Acer campestre L., Ulmus minor Mill., Quercus cerris L., Quercus farnetto Ten. Sprat žbunja je bogat po broju vrsta, u njemu je registrovano ukupno 12 vrsta. U spratu prizemne flore registrovano je ukupno 59 vrsta. Prisutne su biljke iz termofilnih i mezotermnih hrastovih, ali i neke iz bukovih šuma. Izražen je mezofilni karakter ove zajednice, na šta ukazuje i obilno prisusuvo biljaka subatlanskosubmediteranskog flornog elementa, kao što su Ruscus aculeatus L., Euphorbia amygdaloides L., Hedera helix L. i Tamus communis. Karakteristično je prisustvo mediteranskog flornog elementa oštrolisne kostrike (Ruscus aculeatus L.), zbog čega je izdvojena subasocija aculeatetosum.

Analizom spektra areal tipova utvrđeno je da istraživana zajednica kitnjaka i graba ima srednjeevropski karakter, dok je prema spektru životnih oblika fanerofitskohemikriptofitskog karaktera, sa povećanim učešćem geofita.

S obzorom da je Kosmaj zaštićeno područje, sa značajnim prirodnim, biološkoekološkim, estetskim i kuumlturno-istorijskim vrednostima, istraživanje vegetacije ovog područja predstavlja polaznu osnovu za planiranje uzgojnih potreba, kao važnih činilaca u obezbeđenju posebnih namena, koje ove šume imaju. 